American Journal of Applied Sciences 6 (11): 1880-1884, 2009

ISSN 1546-9239

(C) 2009 Science Publications

\title{
Chemical Characteristics of Compost and Humic Acid from Sago Waste (Metroxylon sagu)
}

\author{
${ }^{1}$ Auldry Chaddy Petrus, ${ }^{1}$ Osumanu Haruna Ahmed, ${ }^{2}$ Ab Majid Nik Muhamad, \\ ${ }^{3}$ Hassan Mohammad Nasir, ${ }^{1}$ Make Jiwan and ${ }^{1}$ Michael Gregory Banta \\ ${ }^{1}$ Department of Crop Science, Faculty of Agriculture and Food Sciences, \\ University Putra Malaysia Bintulu Sarawak Campus, 97008 Bintulu, Sarawak \\ ${ }^{2}$ Department of Forest Management, Faculty of Forestry, \\ University Putra Malaysia, 43400 Serdang, Selangor, Malaysia \\ ${ }^{3}$ Department of Animal Science and Fishery, Faculty of Agriculture and Food Sciences, \\ University Putra Malaysia Bintulu Sarawak Campus, 97008 Bintulu, Sarawak, Malaysia
}

\begin{abstract}
Problem statement: Agriculture waste such as Sago Waste (SW) has a potential to cause pollution either on land or in water. In order to reduce this problem, a study was conducted to investigate the effect of three different treatments on the chemical characteristics of compost and humic acid from SW. Approach: The study had three treatments which were: T1: SW $(80 \%)+$ chicken feed $(5 \%)+$ chicken dung slurry $(5 \%)+$ molasses $(5 \%)+$ urea $(5 \%), \mathrm{T} 2: \mathrm{SW}(80 \%)+$ chicken feed $(10 \%)+$ chicken dung slurry $(5 \%)+$ molasses $(5 \%)$ and T3: SW $(80 \%)+$ chicken feed $(10 \%)+$ chicken dung slurry $(5 \%)+$ urea $(5 \%)$. Composting was done for 60 days in a white polystyrene box with a size of $61.5 \times 49 \times 33.5 \mathrm{~cm}$. The composts were analyzed for $\mathrm{pH}$, total nitrogen, organic carbon, organic matter, ash, Cation Exchange Capacity (CEC), phosphorus and HA using standard procedures. Results: All treatments did not reach thermophilic phase. Compost of T2 had high quality ( $\mathrm{pH}$, total nitrogen, organic carbon, organic matter, ash, Cation Exchange Capacity (CEC), phosphorus and HA) compared to T1 and T3. The yield of HA of T2 was also significantly higher compared to those of T1 and T3. The compost characteristics of T1 and T3 were similar. The chemical characteristics of HA the 3 treatments were within the standard range reported by other researchers. Conclusion: T2 is more efficient in producing mature and good quality compost in 60 days compared to T1 and T3.
\end{abstract}

Key words: Sago Waste (SW), compost, Humic Acid (HA)

\section{INTRODUCTION}

It is estimated that about 60 million tonnes of sago starch, extracted from sago palms, are produced per annum in south-east $\mathrm{Asia}^{[1]}$. Most of the factories are built near riversides where Sago Waste (SW) is likely to be discarded into rivers, a practice which may cause water pollution. Some researchers have used SW as substrate for cultivation of edible mushrooms ${ }^{[2]}$, animal feed, production of enzymes ${ }^{[3]}$ and absorbents ${ }^{[4]}$. SW also can be used for composting where the Humic Acids (HAs) can be extracted from the mature compost and can be treated as the backbone of fertilizer.

Humic acids are imported from other countries at a high cost into Malaysia because of cheap source of this acid. The use of humates is being as an organic based fertilizer compared to inorganic fertilizers which have implicated in environmental pollution due to unbalanced has been a global concern. Humic acids are the main and more stable component of organic matter, hence they contribute to soil fertility and soil health ${ }^{[5]}$. Besides that, HA regulates the carbon cycle and the release of nutrients including $\mathrm{N}, \mathrm{P}$ and $\mathrm{S}$ in the soil ${ }^{[6]}$.

As one of the means of utilizing SW, a study was conducted to investigate the chemical characteristics of $\mathrm{HA}$ and compost from SW.

\section{MATERIALS AND METHODS}

The SW was collected from Nit Sei in Mukah, Sarawak, Malaysia. The SW was air-dried and used for the compost. Composting was done inside a white polystyrene box with a size of $61.5 \times 49 \times 33.5 \mathrm{~cm}$. The study had the following treatments:

T1: SW (80\%)+chicken feed (5\%)+chicken dung slurry $(5 \%)+$ molasses $(5 \%)+$ urea $(5 \%)$

Corresponding Author: Osumanu Haruna Ahmed, Department of Crop Science, Faculty of Agriculture and Food Sciences, University Putra Malaysia Bintulu Campus, Sarawak, Malaysia Tel: +6086855406 Fax: +6086855415 
T2: SW $(80 \%)+$ chicken feed $(10 \%)+$ chicken dung slurry $(5 \%)+$ molasses $(5 \%)$

T3: SW (80\%)+chicken feed $(10 \%)+$ chicken dung slurry $(5 \%)+$ urea $(5 \%)$

The ambient and compost temperatures were taken daily (morning and evening). The temperature of the compost was monitored until it equaled ambient temperature after which it was analyzed for $\mathrm{pH}$, total nitrogen, organic carbon, organic matter, ash, Cation Exchange Capacity (CEC), phosphorus and HA using standard procedures. The moisture content of the compost ranged between $50-70 \%^{[7]}$ and turning was done once a week.

The HA was isolated by the method of Stevenson ${ }^{[8]}$ but with some modifications. The compost and hydroxide $(0.002 \mathrm{M})$ were placed inside a polyethylene bottle in a ratio of 1:10 (weight: Volume basis). The mixture was shaken at $240 \mathrm{rpm}$ for $24 \mathrm{~h}$ at room temperature. Afterwards, the mixture was centrifuged for $15 \mathrm{~min}$ at $10,000 \mathrm{rpm}$. The dark-colored supernatant liquid containing HA was decanted, filtered using Whatman filter paper number 2, $\mathrm{pH}$ of the liquid adjusted to 1.0 using $6 \mathrm{~N} \mathrm{HCl}$ and allowed to stand at room temperature for $24 \mathrm{~h}$. The suspension containing HA was transferred into polyethylene bottle and centrifuged at $10,000 \mathrm{rpm}$ for $10 \mathrm{~min}$. The HA was purified by the method of Ahmed et al. ${ }^{[9]}$, by using distilled water and through centrifugation at $10,000 \mathrm{rpm}$ for $10 \mathrm{~min}$ to reduce mineral matter and $\mathrm{HCl}$ during acidification. After the purification, the HA was oven dried at $40^{\circ} \mathrm{C}$ until constant weight was attained.

The ash and organic carbon contents of the HA were determined by the dry combustion method ${ }^{[10]}$. The functional group analysis was done according to Inbar et al. ${ }^{[11]}$ where $20 \mathrm{mg}$ of HA was dissolved in $4 \mathrm{~mL}$ of $0.08 \mathrm{M} \mathrm{NaOH}$ and shaken for $30 \mathrm{~min}$ at $180 \mathrm{rpm}$. The solution was titrated with $0.10 \mathrm{M} \mathrm{HCl}$ to $\mathrm{pH} 2.5$ (within $15 \mathrm{~min}$ ). Carboxyl content was calculated based on the amount of acid required to titrate the suspension between $\mathrm{pH} 8$ and the end point (approximately $\mathrm{pH} 3$ ). Phenol content was calculated by assuming that $50 \%$ of the phenols dissociated at $\mathrm{pH} 10$. Total acidity was calculated by summation of the carboxyl and phenols. $\mathrm{E}_{4} / \mathrm{E}_{6}$ determined by the method of Campitelli and Ceppi $^{[5]}$ and analyzed using UV-Vis spectrophotometer (Perkin-Elmer Lambda 11).

Analysis of Variance (ANOVA) and General Linear Model (GLM) were used to test the effect of treatments while means of treatments were compared using Tukey's Test. Statistical Analysis System (SAS Ver. 9.2) was used for the statistical analysis.

\section{RESULTS}

Figure 1 shows the trend of the temperature of the composted SW with different treatments. The compost temperatures for all the treatments were below thermophilic stage which begins from $45^{\circ} \mathrm{C}$ and above ${ }^{[12]}$. Only $\mathrm{T} 2$ reached a temperature more than $40^{\circ} \mathrm{C}$ and was in the mesophilic phase for eight weeks and gradually decreased to equal ambient temperature (Fig. 1). In addition, the compost of T2 matured in 60 days while those of $\mathrm{T} 1$ and $\mathrm{T} 3$ were less mature at this period. The temperature of $\mathrm{T} 1$ and $\mathrm{T} 3$ were in ambient temperature for weeks and gradually increased after 20 days.

The $\mathrm{pH}, \mathrm{C} / \mathrm{N}$ ratio, $\mathrm{CEC}$, ash and organic matter of T1 and T3 were similar but these chemical characteristics were statistical different from that of $\mathrm{T} 2$. The $\mathrm{C} / \mathrm{P}$ ratio of $\mathrm{T} 1$ was the highest, followed by $\mathrm{T} 3$ and T2 (Table 1).

The chemical characteristics of HA for T1, T2 and T3 of SW compost are shown in Table 2. The $E_{4} / E_{6}$ which indicates humification index was significantly different for all of the treatments. Carbon and ash are related where $\mathrm{T} 1$ had the same effect with $\mathrm{T} 2$ and $\mathrm{T} 3$. The phenolic group was 200 for T1, T2 and T3 respectively. In the case of carboxylic group, that of T3 was not significant different from those of $\mathrm{T} 1$ and $\mathrm{T} 2$

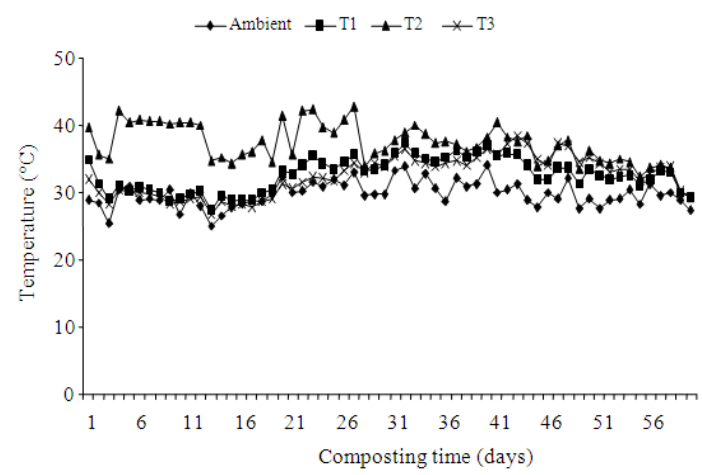

Fig. 1: Compost in different treatments (T1, T2 and T3) and ambient temperature during SW composting

Table 1: Comparison of the chemical characteristics in different treatments (T1, T2 and T3) of SW composting

\begin{tabular}{lcrrc}
\hline & \multicolumn{1}{c}{$\mathrm{T} 1$} & $\mathrm{~T} 2$ & $\mathrm{~T} 3$ & Standard range $^{[13]}$ \\
\hline $\mathrm{E}_{4} / \mathrm{E}_{6}$ & $8.26^{\mathrm{a}}$ & $8.58^{\mathrm{a}}$ & $8.43^{\mathrm{a}}$ & $7-8$ \\
Carbon & $55.92^{\mathrm{ab}}$ & $56.83^{\mathrm{a}}$ & $55.11^{\mathrm{b}}$ & $56-62$ \\
Phenolic & $200.00^{\mathrm{a}}$ & $200.00^{\mathrm{a}}$ & $200.00^{\mathrm{a}}$ & $240-540$ \\
Carboxylic & $250.00^{\mathrm{b}}$ & $300.00^{\mathrm{a}}$ & $283.00^{\mathrm{ab}}$ & $150-440$ \\
Total acidity & $450.00^{\mathrm{b}}$ & $500.00^{\mathrm{a}}$ & $483.00^{\mathrm{ab}}$ & $500-700$ \\
\hline
\end{tabular}

Different letters indicate significant difference between means using Tukey's Test at $\mathrm{p}=0.05$ 
Am. J. Applied Sci., 6 (11): 1880-1884, 2009

Table 2: Chemical characteristics of HAs extracted from different treatments (T1, T2 and T3) of SW composting

\begin{tabular}{|c|c|c|c|c|}
\hline & Initial & $\mathrm{T} 1$ & $\mathrm{~T} 2$ & $\mathrm{~T} 3$ \\
\hline $\mathrm{pH}$ & 4.58 & $6.86^{\mathrm{b}}$ & $7.397^{\mathrm{a}}$ & $6.743^{b}$ \\
\hline $\mathrm{C} / \mathrm{N}$ ratio & 790.10 & $44.12^{\mathrm{a}}$ & $27.33^{\mathrm{b}}$ & $41.43^{\mathrm{a}}$ \\
\hline $\mathrm{C} / \mathrm{P}$ ratio & 4485.42 & $249.67^{\mathrm{a}}$ & $57.82^{\mathrm{c}}$ & $157.103^{\mathrm{b}}$ \\
\hline $\mathrm{CEC}\left(\mathrm{cmol} \mathrm{kg}^{-1}\right)$ & 14.90 & $119.33^{b}$ & $238.89^{\mathrm{a}}$ & $165.33^{\mathrm{b}}$ \\
\hline $\operatorname{Ash}(\%)$ & 4.53 & $6.74^{\mathrm{b}}$ & $20.93^{\mathrm{a}}$ & $8.14^{\mathrm{b}}$ \\
\hline Organic matter $(\%)$ & 95.50 & $93.26^{\mathrm{a}}$ & $79.07^{\mathrm{b}}$ & $91.86^{\mathrm{a}}$ \\
\hline Humic acid (\%) & 0.02 & $0.55^{\mathrm{b}}$ & $1.15^{\mathrm{a}}$ & $0.44^{\mathrm{b}}$ \\
\hline
\end{tabular}

however, the contents of the carboxylic group of T1 and T2 were statistically different. The total acidity of T2 was significantly different from that of $\mathrm{T} 1$ but not $\mathrm{T} 3$. The chemical characteristics for all treatments were mostly in the standard range $\mathrm{e}^{[13]}$.

\section{DISCUSSION}

Although T2 did not reach thermophilic stage, its compost matured in 60 days and this may due to maximum microbial diversity during the mesophilic stage $40-45^{\circ} \mathrm{C}^{[14]}$. The abundance of readily available and easily digestible substrate (e.g., sugars, starches, simple protein compounds) might have ensured that the microorganisms were active. Relatively, low temperature in the compost facilitated the growth and respiration of micro-organisms such as aerobic mouldfungi and bacteria whereas high temperature was due to oxidation of cellulosic materials ${ }^{[15]}$. Lignin was degraded slowly in the mesophilic stage perhaps due to increase in fungal activity ${ }^{[14]}$. According to Smidt et al. ${ }^{[16]}$, glucose can maintain a certain level of microbial activity which was perhaps from the molasses and SW itself. Cayuela et $a l^{[17]}$ reported that fungi have the ability to produce enzymes that are able to degrade lignin and had attributed to the reduction of easily degradable organic compounds and the subsequent decrease in bacteria ${ }^{[18]}$. This may be one of the reasons why the compost did not reach the thermophilic stage.

The presence of urea in T1 and T3 may have probably increased the ammonia emission. Large quantity of nitrogen may limit carbon availability as a source of energy for the microbes. This slowed down the decomposition process of $\mathrm{T} 1$ and $\mathrm{T} 3$ from day one until day twenty. The loss of $\mathrm{N}$ through ammonia release then can be available again when the microorganisms die. This can be shown by the temperature of $\mathrm{T} 1$ and $\mathrm{T} 3$ which is the indicator of microbial activity ${ }^{[19]}$. The temperature of $\mathrm{T} 1$ and $\mathrm{T} 3$ increased after 20 days (Table 1). In terms of time reduction, $\mathrm{T} 2$ is more efficient because its compost matured in 60 days while those of T1 and T3 needed longer time to reach maturity.

The $\mathrm{pH}$ of the composts (T1, T2 and T3) increased from acidic to neutral due to degradation of acid-type compounds like carboxylic and phenolic groups or mineralization of compounds such as protein, amino acids and peptides to ammonia ${ }^{[20,21]}$. The $\mathrm{C} / \mathrm{N}$ and $\mathrm{C} / \mathrm{P}$ ratios decreased due to mineralization. The decreased in organic matter content was caused by mineralization and humification ${ }^{[20]}$ resulting in the increase of ash content and HA. High content of ash resulted in high content of minerals which also reflected the increase in Cation Exchange Capacity (CEC). CEC suggests high amount of available minerals in the compost. Available minerals are very essential for plant growth and development. The higher content of HA at the end of the composting period compared to before composting suggests the occurrence of humification and stability of the compost ${ }^{[22]}$ which had also increased compared to the uncomposted material.

High $\mathrm{E}_{4} / \mathrm{E}_{6}$ of the regardless of treatment indicates the presence of HA with low molecular weight ${ }^{[13]}$. High $\mathrm{E}_{4} / \mathrm{E}_{6}$ ratio reflects a low degree of aromatic condensation and presence of a relatively large proportion of alipathic structure indeed ${ }^{[23,24]}$. It has also been reported that composts have lower degree of aromatization than soil ${ }^{[25]}$. The carbon content of the HA of the composted SW was in the range of the standard values. The values of carboxyl-COOH, phenolic-OH and total acidity of $\mathrm{HA}$ of the $\mathrm{SW}$ were also consistent those of standard range ${ }^{[13]}$.

\section{CONCLUSION}

$\mathrm{T} 2$ is more efficient in producing mature and good quality compost in 60 days compared to T1 and T3.

\section{ACKNOWLEDGEMENT}

This study was supported by a Fund of Ministry of Agriculture and Agro-based Industry Malaysia entitled "Utilization of sago waste in animal production". The authors acknowledge the assistance of the staffs of University Putra Malaysia, Bintulu Sarawak Campus, Malaysia.

\section{REFERENCES}

1. Wang, W.J., A.D. Powell and C.G. Oates, 1996. Sago starch as a biomass source: Raw sago starch hydrolysis by commercial enzymes. Bioresour. Technol., 55: 55-61. http://www.cheric.org/research/tech/periodicals/vol _view.php?seq=361330 
2. Haska, N., 2002. The utilization of the fibrous residue of sago palm as a substrate for the cultivation of edible mushrooms. New Front. Sago Palm Stud., http://sciencelinks.jp/jeast/article/200407/000020040704A0199243.php

3. Singhal, R.S., J.F. Kennedy, S.M. Gopalakrishnan, A. Kaczmarek, C.J. Knill and P.F. Akmar, 2007. Industrial production, processing and utilization of sago palm-derived products. Carbohydrate Polymers, $\quad 72$ : 1-20. DOI: 10.1016/j.carbpol.2007.07.043

4. Quek, S.Y., D.A.J. Wase and C.F. Forster, 1998. The use of sago waste for the sorption of lead and copper. Water SA., 24: 251-256. http://cat.inist.fr/?aModele $=$ afficheN\&cpsidt $=2379350$

5. Campitelli, P. and S. Ceppi, 2008. Effects of composting technologies on the chemical and physicochemical properties of humic acids. Geoderma, 144: 325-333. DOI: 10.1016/j.geoderma.2007.12.003

6. Kalsom, M.S.U., H. Nur, A.A. Norlea and S. Ngaspan, 2006. Characterization of humic acid from humification of oil palm empty fruit brunch using Trichoderma viride. J. Trop. Agric. Food Sci., $\quad 34$ : 165-172. http://works.bepress.com/cgi/viewcontent.cgi?articl $\mathrm{e}=1023 \&$ context=hadi_nur

7. Brady, N.C. and R.R. Weil, 2002. The Nature and Properties of Soils. 13th Edn., Pearson Education, Inc., New Jersey, ISBN: 0130167630, pp: 960.

8. Stevenson, F.J., 1994. Humus Chemistry: Genesis, Composition, Reactions. 2nd Edn., John Wiley and Sons, New York, ISBN: 0471594741, pp: 512.

9. Ahmed, O.H., M.H.A. Husni, A.R. Anuar, M.M. Hanafi and E.D.S. Angela, 2004. A modify way of producing humic acid from composed pineapple leaves. J. Sustain. Agric., 25: 129-139. http://d.wanfangdata.com.cn/NSTLQK_NSTL_QK 8614583.aspx

10. Chefetz, B., P.H. Hatcher, Y. Hadar and Y. Chen, 1996. Chemical and biological characterization of organic matter during composting of municipal solid waste. J. Environ. Qual., 25: 776-785. http://jeq.scijournals.org/cgi/content/abstract/25/4/776

11. Inbar, Y., Y. Chen and Y. Hadar, 1990. Humic substances formed during the composting of organic matter. Soil Sci. Soc. Am. J., 54: 1316-1323. http://soil.scijournals.org/cgi/content/abstract/54/5/ 1316

12. Sundberg, C. and H. Jonsson, 2008. Higher $\mathrm{pH}$ and faster decomposition in biowaste composting by increased aeration. Waste Manage., 28: 518-526. DOI: 10.1016/j.wasman.2007.01.011
13. Tan, K.H., 2003. Humic Matter in Soil and the Environment: Principles and Controversies. Marcel Dekker, Inc., New York, ISBN: 0-8247-4272-9, pp: 408.

14. Saludes, R.B., K. Iwabuchi, A. Kayanuma and T. Shiga, 2007. Composting of dairy cattle manure using a themophilic-mesophilic sequence. Biosyst. Eng., 98: 198-205. DOI: 10.1016/j.biosystemseng.2007.07.003

15. Nelson, M.I., T.R. Marchant, G.C. Wake, E. Balakrishnan and X.D. Chen, 2007. Self-heating in compost piles due to biological effects. Chem. Engi., 62: 4612-4619. DOI: 10.1016/j.ces.2007.05.018

16. Smidt, E., K. Meissl, M. Schmutzer and B. Hinterstoisser, 2008. Co-composting of lignin to build of humic substances-strategies in waste management to improve compost quality. Ind. Crops Prod., 27: 196-201. DOI: 10.1016/j.indcrop.2007.07.007

17. Cayuela, M.L., M.A. Sanchez-Monedero and A. Roig, 2006. Evaluation of two different aeration systems for composting two-phase olive mill wastes. Process Biochem., 41: 616-623. DOI: 10.1016/j.procbio.2005.08.007

18. Lazcano, C., M. Gómez-Brandón and J. Domínguez, 2008. Comparison of the effectiveness of composting and vermicomposting for the biological stabilization of cattle manure. Chemosphere, 72: 1013-1019. DOI: 10.1016/j.chemosphere.2008.04.016

19. Veeken, A., K. Nierop, V. de Wilde and B. Hamelers, 2000. Characterization of $\mathrm{NaOH}-$ extracted humic acids during composting of a biowaste. Bioresour. Technol., 72: 33-41. DOI: 10.1016/S0960-8524(99)90096-2

20. Bustamante, M.A., C. Paredes, F.C. MarhuendaEgea, A. Pérez-Espinosa, M.P. Bernal and R. Moral, 2008. Co-composting of distillery wastes with animal manures: Carbon and nitrogen transformations in the evaluation of compost stability. Chemosphere, 72: 551-557. DOI: 10.1016/j.chemosphere.2008.03.030

21. Gil, M.V., M.T. Carballo and L.F. Calvo, 2007. Fertilization of maize with compost from cattle manure supplemented with additional mineral nutrients. Waste Manage., 28: 1432-1440. http://www.ncbi.nlm.nih.gov/pubmed/17624756

22. Tomati, U., E. Galli, F. Fiorella and L. Pasetti, 1996. Fertilizers from composting of olive-mill wastewaters. Int. Biodeteriorat. Biodegradat., 38: 155-162. DOI: 10.1016/S0964-8305(96)00044-3 
23. Campitelli, P.A., M.I. Velasco and S.B. Ceppi, 2006. Chemical and physicochemical characteristics of humic acids extracted from compost, soil and amended soil. Talanta, 69: 1234-1239. DOI: 10.1016/j.talanta.2005.12.048

24. Rivero, C., T. Chirenje, L.Q. Ma and G. Martinez, 2004. Influence of compost on soil organic matter quality under tropical conditions. Geoderma, 123: 355-361. DOI: 10.1016/j.geoderma.2004.03.002
25. Wei, Z., B. Xi, Y. Zhao, S. Wang, H. Liu and Y. Jiang, 2007. Effect of inoculating microbes in municipal solid waste composting on characteristics of humic acid. Chemosphere, 68: 368-374.

DOI: 